\title{
多機能筋カトレーニング装置の開発
}

\section{Development of Multi Functional Rehabilitation Instrument}

\author{
正 小林 宏（東京理科大） \\ ○林 哲也（東京理科大） \\ 学 西村 力 (東京理科大)
}

\begin{abstract}
A new power rehabilitation tool which does not use weight and has multifunctional mechanism to train muscles required for walking and avoiding taking a fall is proposed in this paper. Break and one-way clutch are used to realize the tool and details in terms of mechanism is discussing in this paper.
\end{abstract}

Key Words: Power rehabilitation, Multifunction, One-way clutch, No use of weight

\section{1. 緒言}

日本では、高齢化社会に伴い、要介護者や障害者吕増加し ている。そのため、近年、介護予防が注目を集めている。こ れは、介護が必要な状態にならないように、栄養面、口腔ケ ア等の様々な視点から高齢者を支え、廃用症候群を防止する 考え方である。その手段の一つとして、パワーリハビリテー ション（パワリハ）という新たなリハビリがある。パワリハ とは、專用のトレーニングマシンを使って強い負荷によって 筋肉を鍛えるのではなく、低負荷・低頻度で無理のない範囲 での運動により、使われなくなった筋肉の力を回復させ、足 の運びや姿勢を改善するものである。その実感や自信が要介 護高龄者に健康に向けた行動を起こさせ、介護予防だけでは なく、自立支援、介護軽減に大きな効果が期待できるトレー ニングである。

そこで本研究では、手軽にトレーニングできるように重り の代わりに電磁ブレーキを用いて負荷を制御し、ワンウェイ クラッチを利用することにより、一台で複数の管肉を鍛える ことのできる方法を考案したので報告する。なお、この研究 では、下半身の筋肉強化のみを対象として研究開発を行った。

\section{2. パワーリハビリテーションの現状}

下半身を鍛えるパワーリハビリテーション機器は、䟽り出 しの動作を行うことで股関節伸筋群, 膝関節伸筋群, 足関節 底屈笳群を鍛える Horizontal leg press (Fig.1)、膝の屈曲伸展 動作を行うことで大腿四頭筋・ハムストリング筋群を鍛える Leg extension Frection (Fig.2)、足の開閉の動作を行うことで股 関節外転筋・内転筋を鍛える Hippabdaction Addiction (Fig.3) の三種類がある。これらの機器は、通常重りを使用して負荷 をかけ、一つの動作、もしくは相反する二つの動作（膝の屈 曲伸展、股の開閉）に特化して開発されている。また、重り を使用しているため非常に重く、使用場所が制限される。
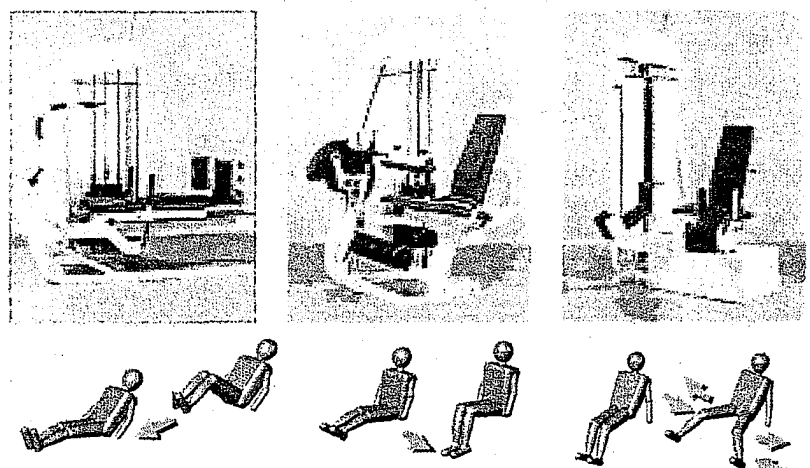

Fig.1 Horizontal leg press
Fig.2 Leg extension friction

\section{3. 多機能リハビリテーション機器の機構}

\section{3-1 必要な動作}

下半身の多機能リハビリテーション機器に必要な動作は、 従来の機器を参考にし、蹴り出し動作,膝の屈曲動作,股の開 閉動作の三動作であると考え、それらの動きを実現できるよ うな機構を検討した。ここで、膝の伸展動作を入れない理由 は，蹴り出し動作においても膝を伸ばす動きをするため、こ れで代用できるからである。

\section{3-2 ワンウェイクラッチの利用}

蹴り出し動作、膝の屈曲動作、股の開閉動作の三動作を一 つの負荷で制御できるように、三個のワンウェイクラッチを 同方向に一つの軸にとりつけることで、それぞれ動作が干渉 しないようにした。この機構を、Fig.4、Fig.5 に基づいて説 明する。

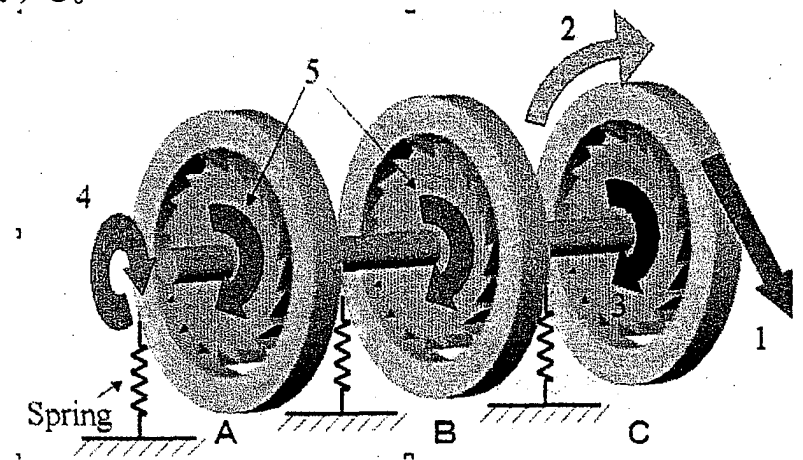

Fig.4 Motion Flow with load

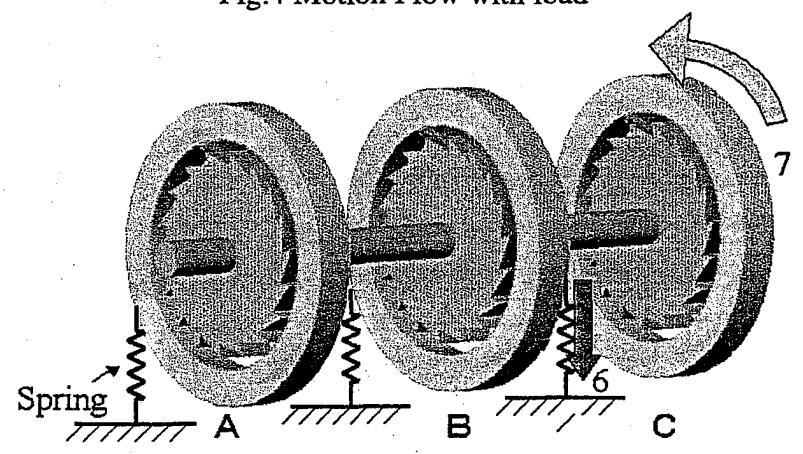

Fig.5 Motion flow after release load

図中の A、B、Cは、簡略化したワンウェイクラッチを示 しており、ワンウェイクラッチの外輪にバネを設置すること で、外輪に力が加わってない場合は初期位置に戻るようにな っている。A、B、Cの外輪は、それぞれ独立の動作（必要 な 3 動作のどれか) を実現する機構と接続されている。 
Fig.4 に示すように、あるある動作を行ってCに 1 方向に カがかかると、ワンウェイクラッチの外輪が 2 のように時計 回りに回り、逆転防止の爪が引つかかり、内輪が 3 ように時 計回りに回る。すると、軸も 4 のように時計回りに回り、A とBの内輪も5のように時計回りに回る。このとき、Aと B の外輪は逆転防止の爪が引っかからないために回転しない。 従って、AとBの動作には影響しない

次に、Fig.5 に示すように、ある動作を行った後に力を抜 くと、Cに取りつかられたバネの復元力によって 6 の方向に 力がかかり、Cの外輪が 7 のように反時計回りに回る。しか し、逆転防止の爪が引つかからないため内輪は回らず軸も回 らない。このような機構を用いれば、多数の動きを一つの負 荷で制御できるようになり、一負荷で多機能のリハビリテー ション機器が可能となる。

\section{4. 多機能リハビリテーション機器の設計 \\ 4-1 全体図}

股の全体の構造と実際に組み立てた物を Fig.6に示す。こ の機器は身長 $2000 \mathrm{~mm}$ の人でも使用できるように設計して おり、全長 $600 \mathrm{~mm}$ 、幅 $450 \mathrm{~mm}$ 、座高の高さ $600 \mathrm{~mm}$ となっ ている。また、使用する際は、股開閉部の上に背もたれのリ クライニング機能、前後スライド機能の座席を載せる。

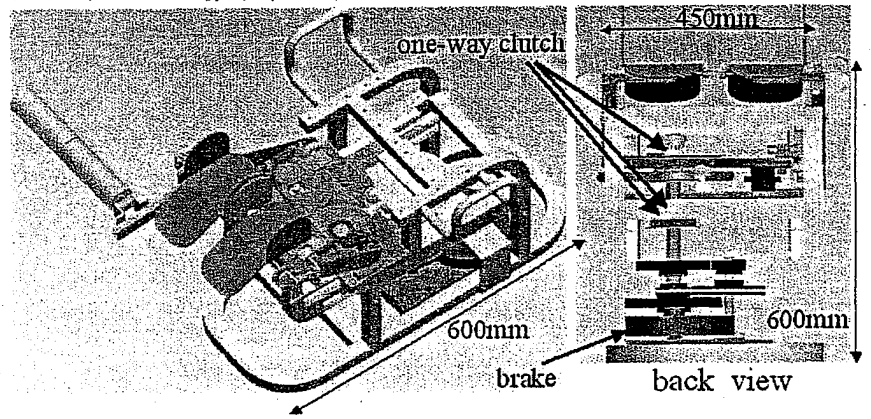

Fig.6 Overview

\section{4-2 股開閉部の設計}

股の開閉機構は、 $140 \mathrm{c} \mathrm{m}$ の人でも使えるよう腿置きを、 股の回転中心から $30 \mathrm{~cm}$ 以内のところに設置し、股の開閉動 作の範囲を $45^{\circ}$ 以上とした。股の開閉部の具体的な構造を以 下に示す。この機構では、左右の腿置きの動作は歯車により 連動している。また、股の開く動作と閉じる動作は、以下に 示す方法により簡単に切り替えることが可能である。

このディスクにはワイヤーが取り付けられておりプーリ を通りワンウィクラッチに繋がっていることで、3.2 で述べ たように軸が回り、ブレーキによって責荷がかかる仕組みと なっている。また、ワンウェイクラッチにはバネが取り付け られているため、ディスクは常に初期位置に戻るように定何 重バネによってカがかかっている。このディスクにある穴と 右腿置きを支えている棒をピンで慗くこことで、腿置きの初期 位置が決まり、股の開閉どちらかの動作か決定する。この際 に腿置きは、動作の方向に合わせて回転できるようになって いる。この股開き動作の様子を Fig.7 に、股閉じ動作の様子 を Fig.8 に示す。
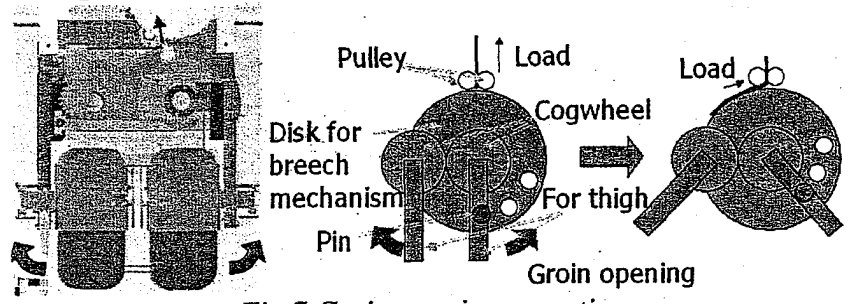

Fig.7 Groin opening operation

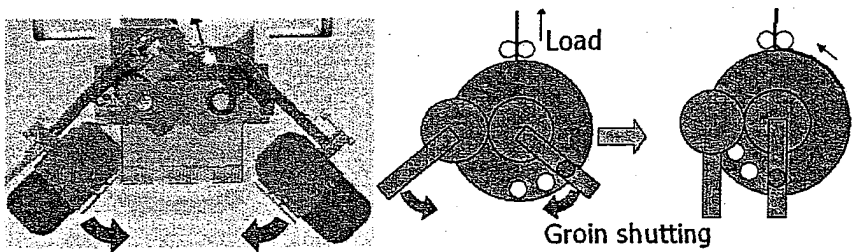

Fig.8 Groin shutting operation

\section{4-3 膝屈曲部の設計}

膝屈曲部の具体的な構像を Fig.9 に示す。股開閉機構が邪 魔にならないように左右に開き、図のように準備する。足置 きにふくろはぎを載せ、膝を曲げると、チェーンが矢印の方 向に動き、スプロケットを通してワンウェイクラッチに繋が って、負荷がかかる仕組みとなっている。

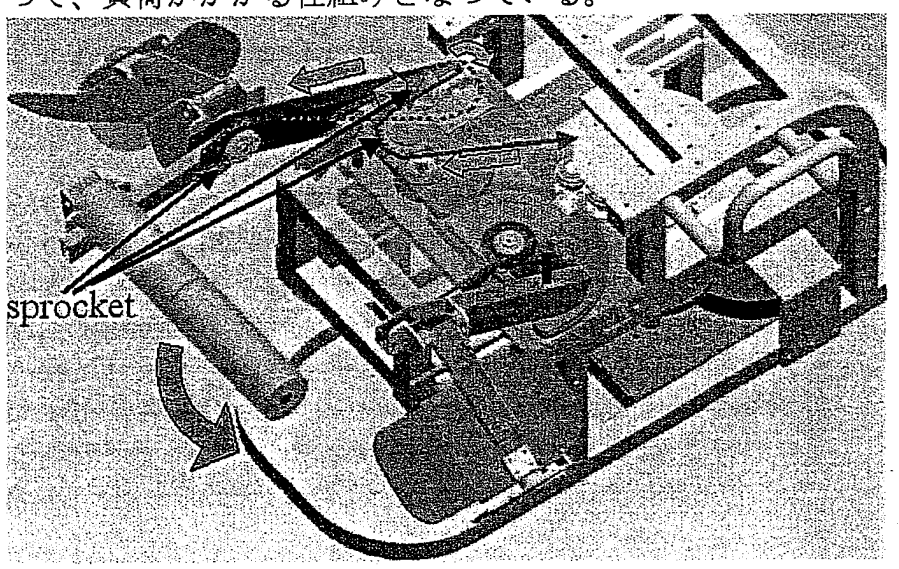

Fig.9 Knee bend part

\section{4-4 脚の蹴り出し部の設計}

脚の蹴り出し部の具体的な構造を Fig.10に示す。これは、 股開閉機構と膝屈曲機構が邪魔にならないように左右に開 き、脚を乗せる板を起こして準備する。䟽り出し部は多段式 のスライドレールによって固定されており、蹴り出すことに よって、ワイヤーによって慗がっているワンウェイクラッチ によって負荷がかかるようになっている。

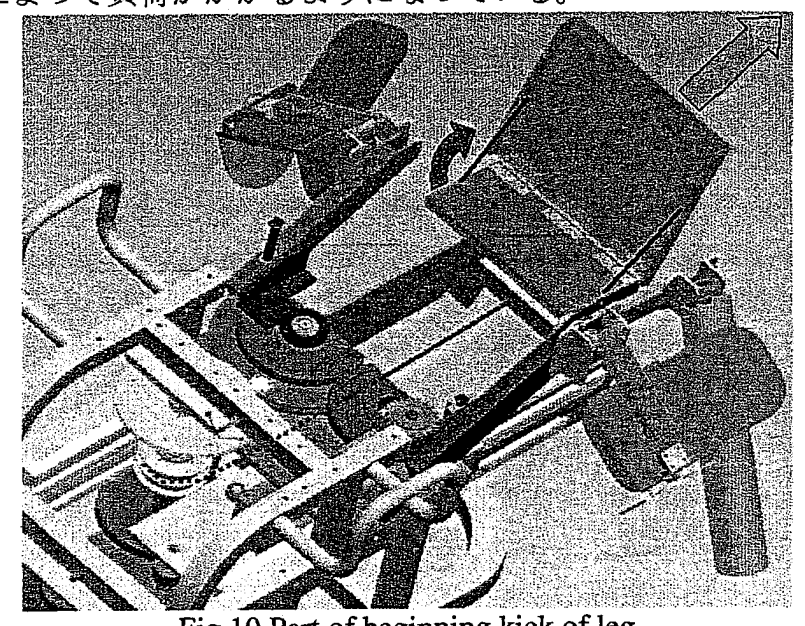

Fig.10 Part of beginning kick of leg

\section{5. 結言}

本研究では、重りを使わずに蹴り出し動作・滕の届曲動 作・股の開閉動作が一台で可能な多機能のリハビリテーショ ン機器を開発した。現在、負荷は電気的に負荷を変更できる マグネットブレーキによって発生させており、簡単に負荷を 変更できるようになっている。今後は、より完成度を高めた 物を作っていき、実際の負荷範囲の検証や、この機器を使用 した提案・実験・検証などを行っていく。 